\title{
Do Salazarismo à Revolução dos Cravos: a História na literatura angolana
}

\author{
Marilúcia Mendes Campos \\ Universidade Federal de Goiás
}

\begin{abstract}
Sei que estás em festa, pá
Fico contente

E enquanto estou ausente

guarda um cravo pra mim.
\end{abstract}

"Tanto mar" (1975), Chico Buarque.

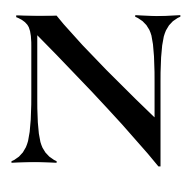

este artigo, visamos refletir sobre as propostas do regime salazarista e sua aplicação e conseqüências em Angola, denunciadas em páginas literárias do escritor angolano Uanhenga Xitu, principalmente em Os sobreviventes da máquina colonial depõem... (1980) $)^{1}$ e Os discursos do "Mestre" Tamoda (1984), ${ }^{2}$ romances metaficcionais, em que a história vai sendo entretecida à narrativa, trazendo à tona o problema da mão-de-obra, um dos pontos-chave da política salazarista, agora revisto sob a ótica do angolano, que dá sua versão sobre o trabalho de contrato, enfatizando a atuação da igreja e de colonos.

Como interessa-nos verificar nesses romances como os angolanos vivenciaram a política de Salazar para Portugal com conseqüências para Angola, não nos deteremos em esboçar as suas diretrizes, mas as apontaremos quando for necessário para a confrontação nos romances.

Desde o início da colonização, os colonizadores, usando como justificativa o intuito de "civilizar" e "catequizar" a população africana, "puseram em prática um modelo colonial em que a população local não

\footnotetext{
${ }^{1}$ XITU, 1980.

${ }^{2}$ XITU, 1984.
} 
só serviu de meio de exploração (...), mas, em considerável medida', pagou com sua própria vida "nas plantações de muitos países do mundo". ${ }^{3}$

Para catequizar a população das colônias, foram enviados os missionários católicos às colônias, como resultado de um tratado ${ }^{4}$ envolvendo o Estado Português e o Vaticano que legitimava o poder colonial em África.

A emigração de colonizadores portugueses para Angola deu-se ao longo dos séculos de dominação de forma heterogênea, dependendo sempre da política da Metrópole para a colônia e da situação políticoeconômica em que se encontrava Portugal.

Em 1930 havia em Angola 3 milhões de habitantes, sendo 42.800 homens brancos e mestiços (estes em maioria), iniciando-se nesse ano um movimento migratório significativo (em parte pela fuga da ditadura e também para resolver problemas de mão-de-obra excedente e de fome pela política de exportação de produtos agrícolas) chegando a população portuguesa a 172 mil pessoas em 1960. ${ }^{5}$ Assim, na década de 30, essa política da Metrópole passou a incluir a "transfusão de população" para Angola para conter o desemprego e o excedente populacional, diminuindo a tensão social entre os portugueses.

A 5 de julho de 1932, Salazar é nomeado para o cargo de presidente do Conselho de Ministros pelo regime militar instaurado em Portugal, representando os interesses de reacionários, latifundiários, da burguesia e do clero.

A maciça emigração de Portugal para Angola nesse período deveuse por um lado aos incentivos do governo de Salazar e, por outro lado, à própria busca de saída por parte dos camponeses e citadinos portugueses pobres "na 'caça' por um lugar melhor para viver. Tratou-se, portanto, de

${ }^{3}$ ZOTOV \& MALIKH, 1990, p. 16. In: MENEZES, 1996, p. 56.

${ }^{4}$ As missões católicas, baseadas no estatuto missionário promulgado pelo governo português a 5 de abril de 1941, e que estava de acordo com a Concordata assinada com o Vaticano, tinham entre seus objetivos sobretudo operar com a "missão civilizadora de Portugal". A Igreja Católica teria colaborado com os colonizadores portugueses no seu intuito de liquidação das culturas indígenas pela imposição da língua portuguesa, pela despersonalização do colonizado e portanto teria colaborado na preparação do colonizado para uma atuação com sucesso do colonizador. Cf. SERRANO, 1988, p. 99.

5 MENEZES, 1996, p. 75. 
um misto de conquista e fuga, porém patrocinadas pelos recursos oficiais da ditadura portuguesa".

A conquista da população nativa pela conversão (paralelamente à exploração econômica) a inseriria no universo cultural do colonizador, cabendo às missões iniciar os colonizados no processo de adaptação disciplinar às normas culturais européias por meio do ensino da língua portuguesa e ainda oferecer segurança espiritual aos colonos afastados da segurança de seus lares europeus. ${ }^{7}$

Os trabalhos dos missionários ganharam força em 1932, sob o regime de Salazar, portanto, que tinha como lema oficial a expressão: "Deus, Família, Trabalho", além de ser um governo intensa e confessadamente católico.

Após a Segunda Guerra Mundial havia mais de 170 missões religiosas e todo o aparato governamental indicava que haveria uma grande massa de angolanos convertidos ao catolicismo, o que acaba não acontecendo, em parte pelo comodismo dos missionários católicos, que preferiam usufruir dos rendimentos estatais e guardar a moral e a fidelidade política dos seguidores da fé cristã.

Já as missões protestantes, embora em número menor, atuavam no campo da educação, produzindo, em função do conteúdo, líderes anticolonialistas como Agostinho Neto.

Embora não se pretenda aqui defender o papel das missões nas colônias, não se pode negar que as protestantes provocaram danos menores, pois o conteúdo do que era ensinado muitas vezes estava ligado à realidade angolana e ainda a outros países e outras realidades, mostrando aos colonizados que Portugal não era superior a todos os outros países da Europa. Essas missões protestantes davam espaço para a manifestação dos sentimentos dos alunos a quem ensinavam e também por essa razão eram colocadas sob suspeita pelo governo colonial.

Nos primeiros anos da década de 30, a crise econômica fez a situação de Portugal piorar, passando as colônias a desempenhar papel fundamental no "sustento" das classes dirigentes, principalmente com a larga produção de algodão, multiplicada dos anos 30 aos 60 por 46.

Após a Segunda Guerra Mundial, com a opinião pública internacional contrária à manutenção dos sistemas coloniais, o governo Salazar

${ }^{6}$ MENEZES, 1996, p. 76.

${ }^{7}$ MENEZES, 1996, p. 78. 
preocupou-se em passar para o mundo a idéia de que era um país único, composto de províncias continentais e ultramarinas. A máquina colonial estava bem engendrada e a verdade sobre o que ocorria em território angolano era bem outra da disseminada pelo Salazarismo: o "Ato Colonial" distinguia o que era um homem branco e um "indígena" e até onde este poderia ir; os jovens, após os 14 anos, recebiam a "carta indígena", comprovando estarem prontos para o trabalho; o assimilado recebia documentos comprovando estar "civilizado" desde que provasse estar seguindo certos quesitos, como "falar corretamente o português", "ter profissão definida", "apresentar bom comportamento", "cumprir o serviço militar" etc.

Para desmentir a idéia propalada por Portugal de que em Angola não se praticava a discriminação racial e de que as diferenças entre brancos e negros eram apenas culturais, e ainda para por abaixo a idéia de um "luso-tropicalismo" propalada pelo sociólogo Gilberto Freyre, um grupo de intelectuais angolanos incumbiu-se de formar o contexto histórico com seu envolvimento na luta pela libertação e também de propiciar a formação e consolidação de um novo contexto.

Foi assim que a partir do início da década de 50 estudantes de Angola e de outras colônias portuguesas que estavam fora do país, ao se profissionalizarem, regressaram a seus países impregnados de idéias libertadoras, dentre eles estavam Amílcar Cabral, Agostinho Neto, António Jacinto, Mário de Andrade, Francisco Tenreiro e outros. Com instrumentos agora para comparar a riqueza da Metrópole e a miséria da colônia, impuseram-se o trabalho de preparar a libertação de Angola.

\section{O fascismo e o "contrato": do primeiro quarto do século XX ao terceiro}

O fascismo, regime político de caráter autoritário, surge na Europa no período entre guerras, com características como o autoritarismo (que subordina os interesses do indivíduo ao Estado), o nacionalismo (que tem a nação como forma suprema de desenvolvimento) e o corporativismo (em que os sindicatos patronais e trabalhistas são os mediadores das relações entre o capital e o trabalho). Originalmente empregado para denominar o regime político implantado pelo italiano Benito Mussolini (1919-43), surge na Alemanha de Hitler (1933-45) como Nazismo; na 
Espanha (1939-75), com Franco, surge o Franquismo; em Portugal (19291974), com o primeiro ministro Prof. Salazar, desenvolve-se o Salazarismo; e, no Brasil, o fascismo acompanha o Estado Novo (1937-45) de Vargas. Como se pode notar, o fascismo se estende por mais tempo na Espanha e em Portugal.

Um dado importante para entendermos o Salazarismo em Angola é pelo trabalho sob contrato, forma de dominação tão cruel que pensar a atuação do regime fascista em Angola é pensar essa forma de trabalho e suas conseqüências para os angolanos, de modo que é sobre ele que nos deteremos na análise desses romances que o tematizaram.

Mário Canova Moutinho, num artigo elaborado para o Colóquio $O$ Fascismo em Portugal, ${ }^{8}$ intitulado "A Etnologia colonial portuguesa e o Estado Novo", ao discorrer sobre o gênero de etnologia praticada por Portugal, lembra as justificativas apresentadas pelo professor Eusébio Tamagni para o povoamento das colônias no "1ํㅡㄹ Congresso Nacional de Antropologia Colonial", " na cidade do Porto, em 1934. A citação é longa, mas julgamos válida por tratar-se de reprodução de documento de difícil acesso, esclarecendo que mantivemos a ortografia original do documento:

Em minha opinião deve, pois, fomentar-se o mais intensamente possível a nossa emigração para as colónias, fazendo todos os esforços e empregando todos os meios para incutir no espírito dos emigrantes a ideia de que elas não são mais do que a continuação da mãe-pátria, e o desejo de lá se fixarem definitivamente, constituindo as suas famílias, acumulando os seus patrimónios e perpetuando a sua raça, como se tivesses permanecido em qualquer canto do território continental.

À ideia, fundamentalmente radicada no espírito dos nossos emigrantes, de que se emigra com o simples objectivo de realizar algumas economias (...) para regressar endinheirado à terra natal, deve sobrepor-se outra mais patriótica e importante: a de que possuímos extensos territórios

\footnotetext{
${ }^{8}$ Vários,1982.
}

${ }^{9}$ Trata-se de uma circular expedida pela Sociedade Portuguesa de Antropologia e Etnologia, anos depois do golpe militar de 1926, declarando que "o conhecimento destas populações (das colónias) sob os seus múltiplos aspectos biológicos, étnicos e sociais está necessariamente na base de qualquer plano racional de organização e aproveitamento das colónias. Assim, os assuntos de que vai ocupar-se o Congresso, revestem além do seu grande interesse científico, uma alta importância nacional". 
ultramarinos (...); onde é possível trabalhar e prosperar com os mesmos, ou melhores, resultados que no continente, levando uma vida semelhante à que aqui fazemos.

À ideia de que nós, portugueses, vamos para a África apenas para comandar pretos, deve sobrepor-se a ideia de que o que mais convém ao interesse nacional e à economia individual dos emigrantes, é a constituição definitiva de núcleos populacionais - casais, aldeias, vilas, etc. - de familias portuguesas, onde as actividades profissionais se exerçam e repartam como se se tratasse de autênticas povoações portuguesas metropolitanas. (...) É preciso, também, que os colonos ofereçam, ou permitam esperar, uma descendência de valor, pois, de contrário, os resultados finais serão, inevitavelmente, desastrosos. Indivíduos inteligentes, de carácter forte e capacidades hereditárias reconhecidas, capazes de manterem em nível elevado a pureza e as energias da raça, de cujos altos destinos estejam firmemente convencidos.

Muitas vezes se apresenta como prova evidente da alta capacidade colonizadora dos portugueses, a pequena repugnância que manifestam nas aproximações sexuais com elementos de outras origens étnicas. É indispensável modificar radicalmente semelhante atitude, se é que ela existe como característica étnica própria.

Quando dois povos, ou duas raças, atingem níveis culturais diferentes e organizam sistemas sociais completamente diversos, as conseqüências da mestiçagem são, necessariamente, desastrosas. ${ }^{10}$

Moutinho cita ainda as idéias apresentadas no Congresso por um outro investigador, A. Silva Correia, a respeito da mão-de-obra nas colônias africanas:

Com relação às populações aborígenes dessas províncias, há várias circunstâncias a considerar, constituindo cada uma delas um dos aspectos daquele problema [o da mão-de-obra] complexo e plurifacetado.

Eles são os seguintes: o recrutamento da mão-de-obra dentro da respectiva colónia e engajamento para fora da província, podendo ser até para o território estrangeiro, e o alistamento militar.

No entanto, o indígena africano não é só nas fileiras que terá de fazer serviço. Há muitos outros ramos de actividade profissional que reclamam o labor dos habitantes (...) dos nossos domínios ultramarinos, sobretudo daqueles onde a carência da mão-de-obra indígena e as imperiosas exigências do trabalho agrícola-industrial o condicionaram ao ponto de o tornar, às vezes e em parte, obrigatório. (...) Assim, nem

${ }^{10}$ Vários, 1982, p. 422. 
todos os indígenas se prestam para o serviço militar, como há outros que são insusceptíveis de trabalhar rudemente nas fábricas.

É, pois, um tal seleccionamento prévio que se pretende organizar para evitar inutilizações pessoais e fracassos econômicos (......11

Nessas citações, que marcam a construção da política do colonizador para incentivar a ida de portugueses em massa para Angola, fica evidente que o trabalho forçado representa uma das mais evidentes provas do atraso e da perversidade do sistema colonial português em relação aos demais colonialismos da época.

Essas proposições apresentadas no Congresso de Antropologia formaram a nova base da etnologia de atuação praticada por Portugal desde a década de 30, embasamento esse totalmente voltado para os interesses políticos e econômicos da Metrópole.

Para que se possa compreender melhor as origens do trabalho forçado, teceremos um breve histórico. Durante o governo de Sousa Coutinho teve início uma política de produção com a aplicação do capital obtido com a escravatura. Em razão dessa política, por volta de 1830 Angola já exportava para Portugal vários produtos agrícolas. Até 1878 os colonos acreditaram que o decreto de 1836, que abolia a escravatura, teria seu prazo dilatado para entrar definitivamente em vigor. Como o esperado não aconteceu, para continuar burlando o decreto o Poder Colonial criou o trabalho forçado, que submetia homens a leis criadas pelo sistema colonial para favorecer seus negócios aviltantes, como a que regulamenta o trabalho indígena, de 1902, ano em que teve início a grande revolta do Bailundo contra o trabalho escravo.

Nessa época a administração de Angola esteve marcada por um caráter de dominação por meios não-pacíficos, tendo início as operações militares ao sul de Angola, que só findam em 1915. Essa forma de dominação perdura oficialmente até 1910 com a implantação da República em Portugal. Com a República e para viabilizar um domínio mais duradouro, os colonizadores procuram empreender uma ocupação mais civil que militar, havendo "certa preocupação" com a saúde e a instrução dos colonizados, cuja versão do angolano veremos nas páginas literárias destacadas.

O governo de Norton de Matos propõe um integracionismo aos poucos, com negros no exército, nas funções públicas e um maior número

${ }^{11}$ Vários, 1982, p. 427. 
de colonos brancos, mas em 1924 é afastado por ser considerado liberal demais e em 28 de maio de 1926 a democracia é banida das idéias sobre a administração colonial.

O Estatuto do Trabalho Forçado nas colônias, desde que fôra estabelecido em 1878 (aplicado então aos escravos recém libertos) e após sua consolidação em 1899, jamais levou em conta a economia de subsistência local e se compunha das categorias: trabalho correcional, obrigatório, contratado, voluntário, cultivo forçado e emigrante.

Pela definição do trabalho por contrato caberiam nessa categoria quase todos os angolanos do sexo masculino, submetidos à administração que passava uma licença de recrutamento a agentes especializados ou a companhias, podendo ser uma licença com facilidade (a administração colaborava) ou sem facilidade (a administração não colaborava com o recrutador, normalmente nativos).

Ainda para elucidar em que consistia esse tipo de trabalho por contrato, buscamos esclarecimentos no testemunho de Costa Andrade que, em sua entrevista a Laban, conta que o contrato

...não começou com os angariadores, começou pelas rusgas (...), invasões das aldeias pelos cipaios (...) que iam a essas aldeias e arrebanhavam jovens e homens com saúde para levá-los para o trabalho do contrato. As rusgas, porém, facilitavam também as fugas. Então, das rusgas evoluíram para os angariadores, passando pelos 'voluntários' - no fundo, uma forma de compra e venda de homens. Houve muitos angariadores que enriqueceram - recebiam por cada homem que eles convenciam, e convenciam-nos com meia dúzia de bagatelas: um bocado de roupa, vinho, algumas missangas para as mulheres, convenciam-nos a ir para um contrato que, nominalmente e inicialmente, era de seis meses, mas as condições do contrato eram de tal ordem que nunca eram seis meses, eram muito mais... O homem que chegava ao contrato recebia um sítio para dormir, uma farda, um cobertor, por vezes sandálias, que lhe eram anotadas, apontadas como sua dívida, e, ao fim de seis meses, ainda estava a dever o que tinha recebido para o trabalho. Efectivamente, tinha de continuar por outros seis meses para pagar aquela dívida! Mas como, entretanto, recebia a comida, às vezes mandava qualquer presente para a família: continuava a dívida... Muitas vezes o contrato, não terminava. Tinha de ficar para pagar a dívida, ou fugir... ${ }^{12}$

${ }^{12}$ LABAN, 1991, p. 467-68. 
Um dos aspectos mais importantes da literatura de U. Xitu é o de oferecer a oportunidade de ouvir o outro lado da história, contada por quem a viveu. E como uma testemunha do muito que viu, viveu e ouviu nos espaços angolanos que percorreu, U. Xitu tematizará o trabalho sob contrato em Os Sobreviventes..., narrativa em que há a denúncia do que foi para os angolanos esse período de sua história, como veremos.

Os maus tratos do colonizador serão denunciados de dentro do sistema colonial, usando como pano de fundo a história de vida do português José das Quintas, ele também vítima do discurso do sistema colonial português, pois, para reduzir a tensão social e aumentar seus lucros, Portugal preparou a "transfusão de população" da metrópole para a colônia com propagandas enganosas, como mencionamos acima.

O desenrolar da narrativa irá desmentindo todo o discurso salazarista, dando a conhecer nas versões do negro e do colonizador o que foi o contrato, sendo que, democraticamente, o narrador dará voz ao colonizador e ao colonizado para a diferenciação de seus pontos de vista.

Nesse romance as personagens que mais têm voz para expor suas idéias são os portugueses a quem será permitido que revele em seu discurso suas arbitrariedades e as bases do discurso colonial português que justificam seus atos arbitrários e desmandos.

As contradições no modo de conceber as relações entre colonizados e colonizadores porá de um lado essa personagem, o José das Quintas, um enfermeiro que tem sua história de vida contada desde seus primeiros anos de escola ainda em Portugal até ir para Angola, envolvido pela campanha de incentivo à emigração, trabalhar como enfermeiro, onde deparará com abusos que contestará, sofrendo as conseqüências desse ato e, de outro lado, vai expor os antigos colonos e suas práticas opressoras, apoiados por alguns maus administradores coloniais misturados aos administradores que estavam cientes da importância de seu trabalho (esta categoria era incumbida de "manter a ordem" para uma melhor exploração das colônias).

A história de Angola no período conta que, embora os novos colonos tivessem pouca ou nenhuma especialização, ficavam sempre em Luanda, sendo mínimo o número deles que adentrava o interior, mas com essa personagem será diferente, pois, contrariando essa tendência, José das Quintas no dia seguinte a sua chegada apresenta-se ao Fiscal do Hospital, que dá as boas-vindas aos recém-chegados, e manifesta sua vontade de ir para o interior. 
O discurso do Fiscal, que é a reprodução do discurso do colonizador português, trata de não deixar dúvida acerca do duro regime colonial até mesmo para os colonos, buscando dessa forma zelar pela manutenção do estado de coisas e de certos privilégios:

... Aqui a vida é diferente de lá. Nem tudo são rosas. Podes ser bom profissional mas se não cumprires com as medidas traçadas pelo Governo, isto é, saber lidar-se com os pretos, com as autoridades gentílicas, não poderás vencer. ${ }^{13}$

Também revela as diferentes maneiras dos colonos definirem o que era o branco português e os "indígenas" (pessoas de raça negra e seus descendentes), que ainda não haviam assimilado a cultura ocidental para estarem sujeitos às mesmas leis que os brancos, seguindo as coordenadas do Acto Colonial, (instituído pelo Decreto 18.570/30 em substituição a um capítulo da Constituição da República Portuguesa): "Sem racismo, sem distinção de cor, preto e branco andam juntos e com a mesma igualdade, mas aos nativos, saber mantê-los a distância". ${ }^{14}$

Pela boca desse Fiscal a farsa das boas relações entre colonizados - independentemente de serem assimilados ou indígenas - e colonizadores é denunciada, contradizendo na prática o discurso salazarista para o mundo:

...o negro pode saber mais do que tu mas tu és tu... Por exemplo: cá na cidade há pretos e mestiços que ocupam lugares de destaque e têm como subordinados funcionários brancos. Mas não penses que sejam superiores, é difícil compreenderes tudo hoje, mas, com o hábito de ver e sentir, aprenderás que acima de tudo está Portugal e sua soberania, que devem ser defendidos custe o que custar". ${ }^{15}$

Esse funcionário português manifesta sua idéia para que a política de unidade nacional seja mantida de forma equânime, sugerindo que os novos colonos, antes de embarcar, deveriam passar "por uma escola onde aprendessem alguns conhecimentos basilares de como se deve manter a política de unidade nacional em todos os sectores", salientando que "Os únicos que estão bem formados e preparados são os do quadro administrativo". ${ }^{16}$

\footnotetext{
${ }^{13}$ XITU, 1980, p. 43.

${ }^{14}$ XITU, 1980, p. 43.

${ }^{15}$ XITU, 1980, p. 43.

${ }^{16}$ XITU, 1980, p. 43.
} 
O Fiscal sugere, portanto, que os novos colonos deveriam aprender, ainda em Portugal, "métodos eficazes" para a submissão do colonizado, como os aplicados pelos Chefes dos Postos Administrativos: "...muitas vezes tinha de esperar horas até que o chefe acabasse de surrar uns quantos pretos", dos quais "o José ouvia o estalar das palmatoadas e dos gritos pungentes dos indígenas". ${ }^{17}$

Esse aprendizado de medidas para a subordinação dos nativos impediria que chegassem a Angola os novos colonos a se manifestarem com idéias de independência "sobretudo nos brancos naturais de Angola". ${ }^{18}$

Como se não fosse possível traduzir bem pela prosa o sofrimento, o narrador recorre também à lírica para introduzir a visão do negro sobre o serviço de contrato neste poema que, composto por U. Xitu no Tarrafal ainda no tempo de cativeiro (1968), é introduzido no romance como uma canção entoada por pessoas que estão voltando do serviço do contrato em três caminhões lotados e passam perto do José das Quintas:

“...É LUTO...

Toda minha vida é luto

Sim, é luto...

Lutulado e conececado

Pela vida

Luto-é-minha cor

Luto-é-minha vida

Marcho-e-danço

Setulando masemba, mas...

Minha vida-é-luto

Minha cor-é-luto

No tambi canto-e-danço

Diquindando

Na junda canto-e-danço

Coelando

Mas... Não distingo

Canto-de-choro

Canto de Junda

${ }^{17}$ XITU, 1980, p. 45.

${ }^{18}$ XITU, 1980, p. 43. 
Dos olhos não caem mais masoxi

Bombaram, Bombaram, Bombaram

(Bulu-Bulu-Bulu... mbom-mbom-mbom...)

Dondaram, Dondaram, Dondaram

(Bulu-Bulu-Bulu... Mdom-Mdom-Mdom...)

Mas reservei um comprido disoxi

Só, só um para ti ó única querida (Angola)

Quando distinguir(ei)

O canto-de-choro

O canto-de-junda" 19

Canto de dor e sofrimento pelos anos todos vividos Lutulado (a apanhar) e conececado (sendo mutilado) na escravidão da qual não consegue perceber o fim, mas dor que não mata a esperança de liberdade para a sua vida de luto, de luta, como expressam os versos finais. Embora não consiga enxergar o dia em que o canto deixará de ser de dor para ser só de festa, alimenta a esperança de que um dia poderá dar "à única querida" Angola o sorriso comprido reservado como um tesouro sob as secas lágrimas. As onomatopéias e a recorrência a palavras em quimbundo, além dos gerúndios em neologismos, aliadas à própria disposição dos versos e estrofes dão a idéia de dança gingada pela sinuosidade que sugere, porém a dança não é de festa e sim de incerteza, envolta pela esperança da chegada do dia em que distinguirá o canto de choro - derramado porque sua cor é de luto e sua vida é de luto - do canto de festa.

O empregado da casa de José das Quintas, o Domingos, que também já foi "ao contrato", pode responder às perguntas sobre esse serviço, as quais servem de roteiro para que o leitor tenha outras versões de como eles são recrutados:

- Ó patrão, vão no contrato saíram do quimbo e vem no Posto para passar guia, depois seguir no Bailundo e daí despachar para qualquer parte onde fica um ano, cadavez seis meses. Alguns contratados vão para café nos Dembos, Vila Salazar, Gabela, Uíge; outros mais vão para pesca de Moçâmedes ou Benguela; ${ }^{20}$

\footnotetext{
${ }^{19}$ XITU, 1980, pp. 48-49.

${ }^{20}$ XITU, 1980, p. 52.
} 
de quem os recruta e paga:

... Aqui cada comerciante arranja as suas pessoas para vender os donos das Fazendas. Cada comerciante recebe quinhentos ou um conto para cada pessoa que arranja. Para o dono da Fazenda tem um empregado ou Gerente ou Director da Fazenda que venha nos Postos ou Concelhos arranjar pessoas que chama angariador. O angariador comerciante também arranja outro angariador já de preto para passar nos quimbos... $;^{21}$

quanto recebe o contratado, se o "angariador recebe $500 \$ 00$ ou um conto de réis por cada preto que arranja”:

- O comerciante dá logo Fuka (dívida) de panos, vinho, enxada e alguma coisa que quer deixar para a família. Paga quando acaba o contrato. Mas às vezes o dinheiro quando volta não chega, encontra data de conta, é imposto, é óbito, é dívida do filho, da mulher, e quando acaba o contrato chega no Posto já está voltar outra vez. A pessoa nem chega mais ir em casa, encontra já outro patrão que está convidar. Ou vai no outro contrato do chefe do Posto. Na Fazenda ou na Companhia para um bocado, o resto recebe tudo no Posto quando voltar no contrato; ${ }^{22}$

quanto ao paradeiro das "mulheres com crianças nas costas e embrulhos na cabeça, homens, rapazes e raparigas" que José vê numa fila:

-... vão para Missão Católica de S. Bento para receber comunhão, aprender doutrina e disciplina de casamento, quem quer casar, receber baptismo e tudo mais quanto é... Cada sanzala vão pessoas na missão e ficam lá uma semana. Levam comida e enxada porque quando fica esperar chegar o dia de confessar, de baptizar, ou de casar ainda começa campinar na granja ou Fazenda do senhor Padre! $!^{23}$

De fato, mulheres grávidas ou com seus bebês às costas, crianças pequenas e mocinhas também eram levadas para o serviço de contrato pelo chefe local em razão dos homens estarem todos em serviço em outros locais, sendo comum vê-las trabalhando em estradas com ferramentas primitivas e transportando pequenos baldes de madeira à cabeça, cheios de terra" ${ }^{24}$

\footnotetext{
${ }^{21}$ XITU, 1980, p. 52.

${ }^{22}$ XITU, 1980, p. 53.

${ }^{23}$ XITU, 1980, p. 53.

${ }^{24}$ DAVIDSON, 1955. In: MENEZES, 1996, p. 71.
} 
José das Quintas percebe pelas explicações do Domingos existirem três tipos de contrato e, didaticamente os separa:

... voluntário, em que o Empresário, através de meios próprios e complicados adquire mão-de-obra braçal ou antes serviçal. O segundo é que tem a legalidade oficial de obrigatoriedade em que, mensalmente, determinados chefes de Posto Administrativo têm de fornecer um X de indígenas para socorrer aquelas empresas que de uma ou de outra forma não conseguirem o número suficiente. Vêm estes indígenas das sanzalas onde são arrancados à força pelos Sobas, Cabos Civis e Sipaios, e a qualquer pretexto para completar o número. Neste contrato dispensa-se ao cumprimento da praxe de pôr todos os contratados na fila diante de autoridade administrativa, do gerente, do angariador, para se saber dos serventes se 'vão de vossa livre vontade, não houve interferências ou influências de pessoas estranhas como Sipaios e de outras autoridades tradicionais, e se já sabem o preço que vão ganhar e a espécie de trabalho a fazer (...) O terceiro contrato é benzido, talvez pareça menos pesado, é o dos padres. Com uma diferença, o tempo parece ser curto de 8 em 8 dias uma ou umas sanzalas; mas se admitirmos beber a hóstia da comunhão todos os meses, por ano teremos 8 x 12 dias, é igual mais de três meses de trabalho por ano. Também aqui não há ração, as alfaias são dos cristãos, o vencimento é a doutrina, é o sacramento do baptismo, é o sacramento do casamento. (...) tinha vantagem por gozar da protecção da Igreja, pois em caso de disputa entre os angariadores o trabalhador que, sendo cristão registado na aldeia, recorresse às boas graças do senhor Padre, nem o primeiro nem o segundo contratante tinha força moral para o arrancar. ${ }^{25}$

Há ainda um outro tipo de contratação de trabalho que segue o modelo do serviço de contrato. Pela acusação feita junto ao chefe do Posto por Canivete - um parente da Luciana, moça negra pela qual José das Quintas se apaixona - contra os procedimentos adotados pela esposa do senhor Costa - um dos comerciantes locais - com relação a pagamento pela lavagem de roupa, toma-se conhecimento de um tipo de trabalho parecido com o de contrato, solicitado pelas senhoras portuguesas, as quais nem chegam a pagar pelo serviço prestado, dado o número sem fim de "dívidas" da empregada, ficando claro que o serviço forçado transformara-se em prática comum na sociedade colonial:

${ }^{25}$ XITU, 1980, p. 53-54. 
- A conversa foi porque a minha mulher costuma lavar roupa do senhor Costa e do senhor Silva (...) quando chega sempre no fim do mês a senhora do senhor Costa para pagar começa pôr falso que falta camisa do menino ou porque falta cueca do patrão. No fim do mês a mulher só paga roupa que falta. Mas as vezes não falta, porque a cueca que a senhora disse que a minha mulher tinha roubado para mim apareceu outra vez na roupa (...) Mas depois tudo apareceu (...) Mas só tem conversa quando chega o dia de pagar dinheiro. ${ }^{26}$

Mais adiante, é o próprio narrador quem conta como eram distribuídos entre as "autoridades" locais os contratados, organizados por um cabo que trazia uma "folha de papel na mão onde destinava o trabalho aos indígenas vindos dos quimbos":

...dez para a lenha da casa do senhor chefe: Fukano, Kemba e...; 5 para o senhor aspirante: fulano e sicrano do quimbo de Cambuengo; 20 para a granja de arroz, são os que vieram do Soba Kandjeke; 70 dos quimbos de... para a estrada que vai até...; e 30 miúdos para pôr terra na estrada de ...; dois estafetas do correio de Bailundo durante esta semana; 2 para o senhor Cardoso, que está aí fora; 5 para o senhor Fadário, só para ajudar pôr milho no moinho... ${ }^{27}$

Para explicar mais um pouco do funcionamento da bem estruturada máquina colonial, o narrador apresenta os beneficiários do serviço de contrato, suas práticas de suborno e conivência, ao mesmo tempo em que denuncia o modo como eram desrespeitados até nos mínimos direitos os contratados:

Come no contratado e do contratado, o administrador e seus subordinados que facilitaram a traficação (...) o chefe do Posto e os Sipaios (...) o médico que inspeccionou os 1000 contratados em 10 minutos, que antes os põe todos nus em pelota e numa fila, mandandoos depois abrir a boca e os sovacos; já está!... (...) o enfermeiro que vacina habilidosamente 2 mil contratados em meia hora, porque depois de chegar o gerente pergunta se ainda demora, passa um maço; já está!... (...) o adjunto de enfermeiro encarregado de desparasitação, com cápsulas ou pérolas de tretracloreto de carbono, manda abrir a boca a todos os contratados e vai atirando algumas cápsulas ao canal,

${ }^{26}$ XITU, 1980, p. 108.

${ }^{27}$ XITU, 1980, p. 106-107. 
e depois de desparasitar uns 20 chega o angariador com os camiões, não pode esperar mais, atira um maço no bolso da bata; já está!... (...) o servente do hospital que com um balde de água e uma caneca graduada da farmácia vai distribuindo o líquido para empurrar as cápsulas da purga; mas, um assobio violineiro do agente ou capataz do angariador, o servente compreende e suspende a operação; já está!... (...) o outro servente que com balde de purgante de sal amargo vai oferecendo o enjoativo aos contratados, franzem a face; mas só chega onde chegaram as cápsulas; não compreende, dizem-lhe que as cápsulas acabaram, só estes, os indígenas que ficaram vão tomar o purgante no local de trabalho e pronto, vai só no quintal para falar; você é burro ou o quê? Já está!... ${ }^{28}$

Além dos serventes do hospital, também os médicos são denunciados por fazer parte dessa engrenagem composta por pessoas sem escrúpulo:

E o médico, delegado da Saúde Pública dos indígenas, averba na guia: 'Sob o ponto de vista Sanitário todos os contratados constantes da folha foram inspeccionados, vacinados e desparasitados.

Delegacia de Saúde do Bailundo, em Teixeira da Silva,... de............ de $194 \ldots$

Delegado de Saúde, (ass.) ${ }^{29}$

Tais denúncias sobre os desmandos praticados pelo colonizador não estão registrados nos livros de história, mas a preocupação do escritor em descrever os detalhes e até em citar nomes reforça o caráter de acontecido aos depoimentos de suas personagens e também aos seus.

Assim como denuncia a prática de suborno e de desrespeito pelo ser humano, denuncia também a ganância dos contratantes e as mortes dos contratados, os desmandos e a rigidez do sistema colonial. A ganância levará à morte muitos dos contratados durante o transporte para o local do trabalho, assim como no trabalho de pesca, como denuncia esta passagem em que o narrador se detém na localização exata do espaço em que os fatos aconteceram:

Lá pelas pescarias de Limagem, Cabo Sta. Maria, Binga, Kapiandala, muitas vidas se perderam no mar por teimosia e malvadez dos seus gerentes. O peixe dava dinheiro e a cegueira ao lucro. Numa madrugada um dos

\footnotetext{
${ }^{28}$ XITU, 1980, p. 61-62.

${ }^{29}$ XITU, 1980, p. 62.
} 
barcos de pesca já cheio de contratados no porto de Benguela para Limagem, insistiu o gerente que levasse mais tambores de óleo, sacos de fuba, feijão e sal. O maquinista opôs-se. Mas o patrão Mário 'Cueca' (...) teimou e ameaçou a tripulação. (...) era conhecido também como o 'mata-pretos' porque no serviço de 'armação', processo de pesca muito perigoso, batia cruelmente os trabalhadores e nos tempos idos atirava ao mar os contratados encontrados a descansar na hora do serviço. (...) Muito distante do porto de Benguela depois de navegar horas, um vendaval que não estava no oráculo do Mário Cueca assolou o barco, que não aguentou, e despeja tudo no mar! Homens, mulheres e crianças gritavam pelos deuses e em todas as línguas que representavam as suas tribos. Salvou-se a tripulação, que sabia nadar, e uns contratados acolhidos por embarcações de pesca que por acaso perto puxavam redes. ${ }^{30}$

Além de serem ludibriados no momento da paga pelo trabalho, além das perdas de vidas no transporte para o local de trabalho e mesmo pelas condições em que era efetuado, além da humilhação, da escravidão, havia também o prejuízo social causado pela separação da família e do lugar onde o colonizado nascera:

O separar-se da mulher durante um ano e o marido voltar com as mãos vazias cria situações sociais difíceis. Lares desfeitos, prostituição, filhos sem instrução, doenças causadas, abandono das lavras. E, se se lembrasse levar a mulher e filhos, sucedia que as vantagens eram quase nenhumas, tinha de começar de novo. ${ }^{31}$

Nestas duas passagens é pela voz de José das Quintas, personagem que representa os poucos portugueses que se manifestaram contrários ao modo como eram tratados os colonizados, que o opressivo sistema colonial é denunciado.

Pensando consigo mesmo a respeito da necessidade de divertir-se e conviver com o que realmente representava a África, José das Quintas define em poucas palavras os maus colonos: “...antes que me dou em doido neste ambiente em que as pessoas a que me devia chegar andam todos atarefados na caça de lucros sem escrúpulos, cometendo uma série de arbitrariedades e crimes". ${ }^{32}$

\footnotetext{
${ }^{30}$ XITU, 1980, p. 63-64.

31 XITU, 1980, p. 68.

${ }^{32}$ XITU, 1980, p. 73.
} 
Nesta passagem em que rebate o discurso dos velhos na chefia do Posto, José das Quintas denuncia a falta de humanidade dos velhos colonos:

... Os tempos mudaram e nós, novos, não queremos pagar os erros que se cometem deliberadamente e, às vezes, sem o mínimo respeito pela dignidade do Homem. (...) Muitos têm agido por sua conta invocando o nome de Portugal, comprometendo toda uma obra bem planejada. Estou crente de que o pouco que se nota do bem nesta terra é obra de poucos mas não da qualidade do velho Silva e de outros. (...) Este cabelo branco, se não veio pelo tempo, então veio por causa dos remorsos... ${ }^{33}$

De fato, como lembra Amadeu José de Freitas, "em 1960, na altura da eclosão da guerra, havia ainda muitos habitantes que tinham menos de quarenta anos de domínio colonial e ainda se lembravam perfeitamente da antiga forma de governo". ${ }^{4}$

As idéias ultrapassadas dos velhos colonos - cheios de poder pela participação nas "campanhas pela pacificação dos indígenas" - que não acompanharam as mudanças estão registradas nestas passagens, em que o narrador cita, extraindo-os diretamente das fontes históricas, nomes dos comandantes das Campanhas, dentre os quais figura Teixeira da Silva, cujo nome até foi dado a um lugar do Bailundo.

Foram recebidos com todas as reverências devidas a pessoas que se julgaram serem os fundadores dos Concelhos e os grandes defensores da política portuguesa em África e os elos de ligação entre os indígenas e os centros urbanos no desenvolvimento comercial e agrícola. (...) Bailundo era o concelho do velho Reis, como Mungo o do velho Silva; nunca se sentiram ultrapassados pelos tempos das campanhas da guerra de Cuanhama, Cuamato e de Bailundo. Como nunca deixaram de citar a bravura e o heroísmo dos oficiais, seus companheiros, das 'Campanhas' como: Roçadas, Teixeira da Silva, Pereira d'Eça, João de Almeida e outros. Eram os capitães 'póstumos' da 1ํㅡㄹ linha distinguidos pela bravura na guerra de 1914, póstumos sim, quando na verdade já eram mortos pelas transformações da época, com a diferença de que eles continuavam vivos e saudosistas. ${ }^{35}$

\footnotetext{
${ }^{33}$ XITU, 1980, p. 110.

${ }^{34}$ FREITAS, 1975, p. 60.

35 XITU, 1980, p. 112.
} 
Mesmo depois do desenvolvimento da colônia e de um aumento progressivo de ocupantes, as revoltas não deixaram de existir assim como, paralelamente, existiram as chamadas grandes campanhas de pacificação, as quais, entretanto, não atingiram seu objetivo, pois os povos atacados não se tornaram pacíficos, pelo contrário, continuaram, progressivamente, com sua resistência.

Em meio a todos os colonos inescrupulosos havia, contudo:

...autoridades administrativas e da Saúde honestos que não aceitavam o suborno. Mas os espertos conseguem por vias incríveis contornar obstáculos. E é o caso do administrador do concelho de Ndalatando. Chegadas as viaturas com os serviçais vindos do Sul. Deu ordens ao cabo de Sipaios em cumprimento da praxe para saber se tinham sido coagidos ou aceitaram de livre vontade o trabalho. O gerente e o angariador, que já tiveram problemas noutras localidades com o mesmo administrador, subornaram o cabo dos Sipaios, que garantiu ajeitar sem perigo.

- Ó cabo, acho que todos estão completos, pergunta lá... - pediu o administrador.

- Ene nga ositu yongulu vuyisole? (Vocês gostam de carne de porco?) - Sim, tchiua - responderam em coro.

- Ñala administrador oyongola okucikuliha nda ocili caco vusole ositu yongulu. (O senhor Administrador deseja saber se de facto gostam da carne de porco.)

Tuyisole calua, tu yiyongola. (Muito, gostamos e queremos.). ${ }^{36}$

Ainda que com boa intenção, os justos administradores eram vencidos pelo esquema de suborno montado, como nesta passagem em que, ao fim da "entrevista", o cabo subornado fazia sua "tradução" oportunista dizendo ao administrador, que não conhecia a língua falada pelos nativos, que os contratados “... disseram que vieram de sua livre vontade, ninguém os obrigou e muitos deles já prestaram trabalhos na fazenda desse senhor e gostaram do trabalho". ${ }^{37}$

A máquina colonial tragava os que lhe atrapalhavam o funcionamento das engrenagens, como o professor socorrido pelo enfermeiro José das Quintas:

\footnotetext{
${ }^{36}$ XITU, 1980, p. 66.

${ }^{37}$ XITU, 1980, p. 66.
} 
- Vejam lá ferido e rasgado desta forma, sou professor diplomado e assimilado, Bilhete de Identidade e taxa militar rasgados aí na secretária e atirados os bocados à minha cara... Porque um fubeiro pretendeu mandar ao contrato o meu irmão seduzindo-o com panos e bujangangas (nadinhas, quinquilharia), e pelo facto de o ir tirar do armazém onde já estava com os outros vizinhos à espera de transporte queixa-me de que sou agitador da sanzala que impede o desenvolvimento económico da Província. Consegue arranjar falsas testemunhas pagas para depor contra $\operatorname{mim}^{38}$

\section{Tragava também alguns portugueses que}

...tinham e manifestavam idéias progressistas, opondo-se a determinações superiores que flagrantemente reduziam os indígenas a bestas de carga, mostrando-se o sistema também bastante rígido para com estes:

Acusados uns de contra-União Nacional, outros de pró-comunistas, logo punham em perigo nas Colónias a linha do regime. Foram transferidos para o Estado da Índia, Macau e Timor nos termos de despachos especiais que não dava tempo ao funcionário para arrumar as malas. Surpreendidos com guias passadas e o substituto de pé com as mobílias nos camiões para descarregar, e o substituído aproveitar os mesmos. Está a andar! !39

Havia, entretanto, além desses colonizadores portugueses interessados no lucro rápido e certo, um poder ainda maior e mais rígido que o do português, posto que o lucro deles e os interesses envolvidos eram ainda maiores, conforme conta o narrador:

Os países capitalistas que tinham investido somas de dinheiro em muitas empresas gozavam de especial influência em Angola, tendo seus representantes, delegados ou gerentes, uma palavra de ordem sobre qualquer entidade oficial, seja qual fosse a sua categoria ou posição social. (...) Um dos magnatas estrangeiros, que vinha de comboio de Dilolo ao Lobito, em viagem de inspecção às minas de cobre e de diamantes da Zâmbia e de Katanga, posto ao corrente do escrito do Intendente (- um relatório em que observava os cruéis tratamentos dados aos contratados, comparando-os aos antigos escravos vendidos para as Américas), ali mesmo no Lobito onde apanhava o barco para Europa, enviou cabograma

\footnotetext{
${ }^{38}$ XITU, 1980, p. 81-82.

39 XITU, 1980, p. 66-67.
} 
e telegramas ao seu país e a Portugal. No dia seguinte não só o Intendente foi transferido para Macau como todos os administradores e chefes de Posto com quem ele se dava foram substituídos. ${ }^{40}$

Como vimos, nessa narrativa a personagem José das Quintas, que aponta para os novos rumos da relação colonizador-colonizado, atua como um intermediador para que as personagens colonizadas possam finalmente expor sua versão sobre o que foi o serviço por contrato, assim como os velhos colonos que também ganham voz na narrativa, só que com esse procedimento o narrador deixa que o colonizador exponha, num discurso, suas práticas desumanas e seu modo inescrupuloso de agir para alcançar maiores lucros com o serviço dos contratados. Com esses procedimentos, democraticamente o narrador permite que o seu leitor "ouça" as versões de colonizado e colonizador sobre o serviço de contrato.

O romance Os sobreviventes... está mais voltado para o plano das definições do que veio a ser esse tipo de trabalho no período colonial, entretanto, é numa história contada por um velho na estação de trem onde Tamoda está, em Os discursos..., que o espaço das ações é o do próprio local onde o contratado está a trabalhar para o comerciante, permitindo essa história, dentro da história de Tamoda, o conhecimento do que ocorria nas lavras, como se a "câmera" do narrador pudesse, no deslocamento de foco, aproximar ainda mais o leitor do que se denuncia.

Esse episódio por meio do qual o narrador conta o que ocorria nas lavras e como o comerciante agia, diz respeito ao comerciante português chamado José da Ronca -identificado por suas ações opressoras e pela sua maneira de falar - que requisitava serviçais nas sanzalas "indígenas" para trabalhar nas suas lavras:

O horário de trabalho para os serviçais era das sete ao meio-dia e das catorze às dezoito horas. Havia empreitadas e quem acabasse ia-se embora. Prometia ao chefe do posto o pagamento do pessoal, mas ele gratificava-os apenas, arranjando subterfúgios de tal ordem que, trabalhando um mês, só pagava metade, apresentando sempre alibis e falsas faltas. O horário estipulado, sim, mas tinha dado ordens ao capataz Adão João que mesmo chegando à hora, se ele não estivesse, o pessoal não largaria o trabalho até que regressasse, isto é, quando viesse da povoação comercial ou da estação dos caminhos de ferro,

${ }^{40}$ XITU, 1980, p. 67. 
onde, por vezes, ficava horas e horas a beber e a conversar (...) resolvia fazer a chamada e o ponto da sua misteriosa relação do livro. (...) Quando os serventes vissem que a hora de largar estava de acordo com a sombra do pau fincado no chão para lhes determinar o descanso, já que o sino nunca mais se ouvia tocar, eles largavam (...) Mas quando ouvissem o trotear traca-traca e o grunhir do cavalo e o chicote a zunir no ar, levantavam-se preocupados. Depois mandava tocar o sino e os alinhava. Abria o livro do ponto e com o lápis na mão ia fazendo a chamada e marcando as faltas com siglas características... ${ }^{41}$

Se os contratados refutassem os apontamentos do comerciante, eram ameaçados com pancadas e cadeia:

- Mas kuseka como? Eu estava a descansar no meu tempo de descanso! - Ai é? A refilar com o branco? Ó capataz Adão, toma o bilhete, leba já este gajo ao senhor chefe do posto para lhe botar uma carga de porrada... ${ }^{42}$

Na temática sobre o contrato, até mesmo os missionários são denunciados, quando pela própria voz deixam transparecer a grande diferença entre o discurso religioso e a prática, pois como lembra Frantz Fanon em seu Os condenados da terra (1979):

... os comunicados triunfantes das missões informam, na realidade, sobre a importância dos fermentos de alienação introduzidos no seio do povo colonizado. Falo da religião cristã e ninguém tem o direito de se espantar. A Igreja nas colônias é uma Igreja de Brancos, uma igreja de estrangeiros. Não chama o homem colonizado para a via de Deus mas para a via do Branco, a via do patrão, a via do opressor. E como sabemos, neste negócio são muitos os chamados e poucos os escolhidos: ${ }^{43}$

A Igreja Católica é denunciada nessa narrativa como uma instituição aliada ao Estado Português, sendo também beneficiada pelo serviço por contrato, explorando aqueles a quem, pelo discurso cristão, deveriam proteger.

Assim, será pela própria voz de um dos padres que a ligação da Igreja ao Estado será denunciada, pois apreende-se pelas palavras de "pai"

\footnotetext{
${ }^{41}$ XITU, 1984, p. 69.

${ }^{42}$ XITU, 1984, p. 70.

${ }^{4}$ FANON, 1979, p. 31.
} 
do missionário que o discurso das missões religiosas católicas postula o conformismo do angolano com sua situação de oprimido.

A narrativa critica esse posicionamento em várias passagens, denunciando as práticas opressoras dos missionários que se aproveitavam também eles do sistema ao usar os angolanos como contratados em suas lavras, em nome de Deus e como forma de pagarem alguma culpa.

No episódio em que um professor da Escola da Missão Protestante é conduzido todo machucado e sob prisão até o Posto Sanitário em que José das Quintas era enfermeiro, o discurso da Igreja Católica, aliada ao Governo Português pela Concordata, e o autoritarismo do colono são desmascarados na fala desse professor:

... Lutar para se libertar de uma situação de sobrevivência todos os meios aceitáveis devem ser utilizados e nunca a Igreja vir com paliativos de jesuísmo levar uma bofetada numa bochecha e dar a outra para levar outra tareia... Tenham paciência não poderei esperar mais pelas trombetas dos anjos que libertarão o mundo e dar o céu aos que sofrem da "sede de justiça". Até quando, até quando, ó Messias? - bradava o professor. - Bolas, carambas, é demais - chorava que nem uma criança. (...) - Vejam lá ferido e rasgado desta forma, sou professor diplomado e assimilado, Bilhete de Identidade e taxa militar rasgados aí na secretária e atirados os bocados à minha cara... ${ }^{44}$

A Igreja Católica, na voz do padre, aconselha o José das Quintas sobre o comportamento ideal do colonizador dentro da colônia, sendo aí desmascarada a incoerência entre discurso e prática religiosa:

...As missões católicas, ao lado do Governo, têm feito grandes progressos na evangelização e dignificação do próprio homem. (...) Fomos nós, como país civilizador do mundo, que consagramos os primeiros bispos negros no Mundo (...) É uma luta difícil e ingrata tirar da mentalidade do indígena o feitiço e quimbanda. Sem isso o meu filho (batia-lhe no ombro) não estaria cá a dar injecções e a curar feridas a esta gente amansada graças à obra divina. (...) Nada mais se exige a todos os portugueses senão os bons exemplos em todos os aspectos para serem seguidos pelo povo ainda atrasado. ${ }^{45}$

\footnotetext{
${ }^{44}$ XITU, 1980, p. 81.

${ }^{45}$ XITU, 1980, p. 95.
} 
Como bem lembra Fanon, "a burguesia colonialista é ajudada em seu trabalho de tranqüilização das massas pela inevitável religião. Todos os santos que estenderam a outra face, que perdoaram as ofensas, que receberam sem sobressalto os escravos e os insultos, são explicados e dados como exemplo". ${ }^{46}$

O texto de Xitu confirma a adoção desse procedimento, já que depois de aconselhar como se fosse um pai, o padre toma fôlego e muda o tom do discurso, revelando, além do racismo, a colaboração da Igreja Católica com a Metrópole:

...O senhor enfermeiro chegou e começou logo a promiscuir-se com os indígenas de uma forma que nos desencoraja. Outra, um professor da Seita Americana que curaste há dias fez neste Posto Sanitário declarações atentatórias à igreja e à soberania portuguesa... ${ }^{47}$

A diferença entre o discurso e a prática da Igreja Católica estará denunciada no debate que José das Quintas estabelece com esses padres que o vão aconselhar sobre seu comportamento em Angola, chegando o enfermeiro a desmascarar o racismo dos padres, a falta de amor e proteção aos que sofrem e a adesão dos missionários católicos ao poder colonial. Aqui também, como vimos, um narrador onisciente usa a prática de dar voz às personagens que quer desmascarar, deixando que elas mesmas exponham seu lado negativo, sem que seja preciso um narrador em terceira pessoa a acusá-las.

Os sobreviventes... é um texto sui generis, pois ao contrário dos outros textos de U. Xitu em que se mescla narrativa e história, ou factual e ficcional, parece que o enredo ficcional desse texto funciona como um tênue véu para a denúncia do que foi o serviço por contrato principalmente durante as primeiras décadas do século XX.

A novela de amor entre o colono José das Quintas e a moça negra Luciana é apenas o fio que conduz a narrativa, pois o texto trata realmente é do depoimento do colonizado sobre o contrato, abrindo espaço também ao colonizador para que mostre seu ponto de vista sobre esse tipo de trabalho criado por Portugal.

\footnotetext{
${ }^{46}$ FANON, 1979, p. 51.

${ }^{47}$ XITU, 1980, p. 95.
} 
Dessa forma, o autor irá mostrar que assim como o trabalho do angolano na cidade, que é um instrumento de desagregação das relações sociais tradicionais, o trabalho escravo também é tratado como desagregador dessas relações, só que este não é opcional, é uma imposição do sistema colonial no qual o angolano é tratado como objeto.

Esse tipo de trabalho, por contrato, desagrega as relações sociais ao retirar de dentro das casas os homens para levá-los aos locais de trabalho por vários meses, afastando-os da sua família e das suas obrigações para com a sanzala, uma vez que leva homens, sem distinguir seu papel social dentro de seu grupo - como o de chefes tradicionais, com os quais o poder central das sanzalas é retirado.

Por meio da ficção, a realidade pode ser organizada e conseqüentemente a história do período, possibilitando aos leitores uma versão angolana a respeito do que representou esse tipo de trabalho para os colonizados.

Como pôde ser observado, o trabalho por contrato fazia mesmo parte da política ocupacionista do colonizador português que na década de 30 ganha fôlego com o salazarismo, como também o fazia o discurso luso-tropicalista, teorizado por Gilberto Freyre.

Os angolanos, entretanto, não aceitaram passivamente essa forma de dominação próxima do irracional, tanto é que na década de 20 uma série de rebeliões é disseminada pelo território angolano, como a do Catete, de Dala Tando e Lucala, do Bié e do Bailundo, todas apoiadas em reivindicações sobre o recrutamento laboral, trabalho forçado e expropriação de terras pelos europeus, sendo que ainda outras revoltas se estenderam pelas décadas de 30 e 40.

A política salazarista se refletiu nas colônias, desmantelando a sociedade angolana: eliminou as formas de poder e organização social tradicionais com a ação das autoridades administrativas, mandando chefes para o serviço de contrato e interferindo nas resoluções dos assuntos mais corriqueiros da comunidade, questões essas assinaladas em Os sobreviventes...

Os testemunhos de U. Xitu e de personagens da História de Angola estão bem mesclados na sua obra ficcional, principalmente em Os discursos e em Os sobreviventes..., e só uma leitura que leve em conta o histórico, ou o contexto histórico, poderá deixar perceber essas marcas retomadas e recontadas agora pelo ponto de vista do colonizado, permitindo o desmoronamento do discurso do colonizador, ou em outros termos, do discurso luso-tropicalista. 
No processo de construção da identidade nacional, a memória exerce importante papel e por meio dela os vários e diversos discursos se entrecruzam, aproximando áreas do conhecimento como a lingüística, a filosofia, a história, a sociologia, a antropologia, a arquitetura dentre tantas. Valendo-se das fontes orais (arquivos vivos, a tradição oral, as manifestações culturais seculares...) ou das arquivísticas (basicamente os documentos escritos), a memória intermedia as estruturas sociais, individuais e coletivas da identidade e os desafios da alteridade. Pensar a literatura na perspectiva desses deslocamentos é uma maneira de permitir que a memória seja evocada e repensada criticamente.

Após quase cinco décadas sob os ditames do regime fascista e há mais de uma em guerra pela independência, Angola passa, depois do abril de 1974, para uma nova fase, a da reconstrução das estruturas físicas destruídas durante a guerra ou quando da saída dos soldados com o término dela e, paralelamente a esse trabalho, um outro se impôs: o da construção da identidade nacional. A Portugal também impôs-se essa necessidade, já que agora nem viviam sob as glórias do passado nem desfrutavam das maravilhas da modernidade. Com "os regressados" (com o fim das guerras coloniais e as Independências, regressaram a Portugal cerca de um milhão de retornados e todo esforço salazarista pela contenção da mão-de-obra excedente explode, tendo demorado muito a ser reabsorvida), a situação ganha dimensões sobre as quais era preciso refletir e agir, pois além da desagregação social, a guerra causou empobrecimento.

Seguiu-se à Revolução do 25 de abril um período bastante conturbado em Portugal, com grandes tumultos e ocupações de propriedade privada. Nas colônias, as lutas pela liberdade são ganhas e as Independências conquistadas. Angola enfrenta uma situação diferenciada, com três partidos lutando para dirigir o país e com apoios de países diferentes, fato que gerou o Acordo do Alvor entre Portugal e os partidos, estabelecendo um governo de transição e, a 11 de novembro de 1975, o MPLA assume a presidência do país, com a missão de reconstruí-lo de acordo com as necessidades dos angolanos e a de ajudar na resposta à pergunta: Quem somos nós? 


\section{Referências Bibliográficas}

DAVIDSON, B. The African Awakening. Londres, 1955. In: MENEZES, Solival S. Dinâmica da transição de uma economia dependente colonial para economia centralmente planejada e sua inflexão recente para economia de mercado. Tese de doutorado, FEA-USP, junho, 1996.

FREITAS, A. J. O longo caminho da liberdade. Lisboa: Moraes editores, 1975.

LABAN, M. Angola - entrevista com escritores. Porto: Fundação Eng. António de Almeida, 1991.

FANON, Frantz. Os condenados da terra. Trad. José Laurêncio de Melo. 2a. ed., Rio de Janeiro: Civilização Brasileira, 1979. (col. Perspectivas do homem, vol. 42, Série Política)

MENEZES, Solival S. Dinâmica da transição de uma economia dependente colonial para economia centralmente planejada e sua inflexão recente para economia de mercado. Tese de doutorado, FEA-USP, junho, 1996.

SERRANO, Carlos H. Angola: Nasce uma Nação: um estudo sobre a construção da identidade nacional. Tese de Doutorado, FFLCH-USP, 1988.

Vários. O Fascismo em Portugal: Actas do Colóquio. Faculdade de Letras de Lisboa: Ed. A Regra do Jogo, 1982 (Coleção Biblioteca de História/12).

XITU, Uanhenga. Os sobreviventes da máquina colonial depõem... 1a. ed., Lisboa: Edições 70, 1980.

XITU, Uanhenga. Os discursos do "Mestre" Tamoda. Lisboa: Ed. Ulisseia, s.d. (o autor informa serem de 1984 as $1^{\underline{a}}$ e $2^{2}$ edições)

ZOTOV, N. \& MALIKH, V. A África de Expressão Portuguesa: Experiência de Luta e de Desenvolvimento. Moscou: Ed. Progresso, 1990. In: MENEZES, Solival S. Dinâmica da transição de uma economia dependente colonial para economia centralmente planejada e sua inflexão recente para economia de mercado. Tese de doutorado, FEA-USP, junho, 1996. 


\section{Resumo}

Neste artigo, visamos refletir sobre as propostas do regime salazarista e sua aplicação e conseqüências em Angola, denunciadas em páginas literárias do escritor angolano Uanhenga Xitu, principalmente em Os sobreviventes da máquina colonial depõem... e Os discursos do "Mestre" Tamoda, romances metaficcionais, em que a história vai sendo entretecida à narrativa, trazendo à tona o problema da mão-de-obra, um dos pontoschave da política salazarista, agora revisto sob a ótica do angolano, que dá sua versão sobre o trabalho de contrato, enfatizando a atuação da igreja e de colonos.

\section{Resumé}

Dans cet article nous nous proposons de réfléchir sur les propositions du régime de Salazar, sur leur application à Angola et leurs conséquences, dénoncées dans des pages de l'écrivain angolais Uanhenga Xitu, surtout Os sobreviventes da máquina colonial depõem...et Os discursos do "Mestre" Tamoda, des romans métafictionnels, où l'histoire s'entremêle au récit, en faisant afflorer le problème de la main d'oeuvre, un des points-clés de la politique de Salazar, revu dans ces romans, sous l'optique de l'écrivain angolais, qui présente sa version sur le contrat de travail, en mettant en évidence l'action de l'église et des colons. 